\title{
la Creación Musical En El Proceso Cinematográfico. Una Perspectiva Crítica
}

\section{Music creation in the film process. A critical approach}

\author{
Dr. José Ángel LÁZARO LÓPEZ \\ Profesor asociado. Universidad Carlos III de Madrid, España. \\ E-mail: jlazaro@hum.uc3m.es \\ (iD) https://orcid.org/0000-0002-8306-6229
}

Fecha de recepción del artículo: 17/06/2020

Fecha de aceptación definitiva: 21/10/2020

\begin{abstract}
RESUMEN
El presente estudio aborda, desde una doble perspectiva, la creación musical dentro de los procesos de creación fílmica. Desde la vertiente académica, la bibliografía al respecto, notablemente escasa desde la perspectiva de la creación, presenta además un anquilosamiento histórico en una serie de lugares comunes que las nuevas iniciativas investigadoras no han logrado trascender, situándose éstas, a través de aproximaciones provenientes de marcos como la musicología, los estudios culturales, o la filosofía, en los márgenes de la teoría propiamente cinematográfica. En cuanto a la situación en el entorno industrial, los usos y rutinas actualmente instaurados, adolecen de los mismos vicios y problemas que ya venían siendo patentes desde las últimas cuatro décadas. A través de la revisión exhaustiva de los trabajos teóricos al respecto, y de la observación, estudio y recabado de experiencias profesionales en el ámbito de la industria cinematográfica, el presente trabajo analiza, no solo las causas de los problemas profesionales en la implementación de la música en las películas, sino su relación con las limitaciones y la falta de especificidad en los estudios teóricos recientes. A partir de este análisis, se proponen líneas de discusión para una readecuación epistemológica y didáctica de los estudios sobre la creación fílmica a través del elemento musical.
\end{abstract}

Palabras clave: Cine; música; análisis de creación; comunicación audiovisual; bandas sonoras; producción de películas.

\begin{abstract}
This research approaches, from a double perspective, music creation within film creation processes. On the one hand, the academic approach, truly scarce in relation to creative processes, exhibits a historical stagnation onto a series of platitudes which the newest research initiatives have failed to overcome. These initiatives, coming from areas such as musicology, cultural studies or philosophy, end up standing on the margins of the proper area of film theory. On the other hand, regarding the situation in the industrial environment, the currently established uses, habits and routines suffer today the same vices, misuses and troubles that were already patent during the last four decades. Through the exhaustive review of the academic sources and the theoretical studies on this topic, and the observation, study and collecting of professional experiences in the area of
\end{abstract}


cinematographic industry, this research analyzes, not only the causes of the professional troubles in the implementation of music in films, but its relationship with the limitations and the lack of specificity in the recent theoretical studies. From this analysis, lines of discussion are proposed toward a didactic and epistemological readjustment of the studies about film creation through the musical element.

Keywords: Cinema; music; creative analysis; audiovisual communication; soundtracks; film production.

\section{Hablar sobre lo inefable. breve introducción crítica}

El campo de los estudios fílmicos, y, en concreto, el que comprende los relacionados con los procesos de creación cinematográfica, se encuentra en la actualidad sometido y limitado por un discurso tutor ${ }^{1}$ establecido e institucionalizado que provoca una serie de riesgos de hondas implicaciones epistemológicas, pedagógicas y profesionales. Este discurso fija el suelo sobre el que se puede debatir sobre el proceso de hacer películas, pero también establece un techo que marca tácita pero firmemente los límites de lo decible y pensable sobre ese mismo proceso. Ahí radica el doble riesgo del discurso tutor: su capacidad para simplificar lo complejo para hacerlo más comprensible, y su capacidad de naturalizar lo construido para hacerlo pasar por la única opción posible (Galindo Pérez, 2018, p. 464). En esta vertiente específica -la de la música- de la teoría fílmica sobre cómo se hacen las películas, la producción académica suma, a los señalados riesgos del discurso tutor, las notables limitaciones que los estudiosos sobre cine evidencian a la hora de tratar todo elemento procedente de lo musical. Históricamente, la música de/en las películas no ha sido objeto de análisis riguroso hasta los años ochenta y noventa del siglo pasado, principalmente como resultado de la visión convencional del sonido como simple añadido o apéndice de la imagen (Stam, 2001, p. 248) y, cuando se había tratado, había sido -con la prácticamente única excepción del texto de Adorno y Eisler aparecido en 1944- de manera condicionada, y sometida a la visión vococentrista denunciada por Michel Chion, en la que la banda de sonido se reducía, en el análisis, a su componente de diálogos entre los personajes (Chion, 1997, p. 252). En los estudios actuales, la teoría fílmica sigue sin proveer la atención necesaria a la perspectiva musical y a sus procesos de creación (Saitta, 2012).

Ante esta situación general, son los campos de la musicología y de los estudios culturales quienes han aportado la mayor parte de los trabajos recientes sobre el tema. Sin embargo, estos estudios, en su gran mayoría, arrancan siempre desde la obra finalizada, y desatienden también los procesos de creación, poniendo, en el caso de los musicólogos, el acento en el análisis estrictamente musical de las piezas presentes en las películas, así como en la reivindicación de los compositores en términos, de nuevo, estrictamente musicales. Así, las limitaciones mostradas por los filmólogos en el terreno de lo musical encuentran su reverso en las de los musicólogos al abordar lo fílmico, generándose una brecha epistemológica entre unas limitaciones y otras, con el consiguiente empobrecimiento metodológico en los trabajos que se vienen

1. El discurso tutor, noción que emana directamente del "sentido tutor" (González Requena, 2006, p. 10), acuñada por González Requena para advertir sobre el conjunto de postulados que consolidan lo que se acepta pensar y decir sobre el cine de Eisenstein, se trata de un concepto que protege un determinado corpus de conocimientos, al mismo que tiempo que oscurece u oculta otros, acerca de todo fenómeno susceptible de estudio (Galindo Pérez, 2018). 
realizando. La gran mayoría de ellos se limitan a confrontar los recursos compositivos de los músicos encargados de partituras de música extradiegética, con la mecanicista concepción teórica de la música como elemento funcional, agregado al elemento cine. La aplicación de análisis en términos fundamentalmente cuantitativos debe ser replanteada en el campo de la comunicación audiovisual en favor de metodologías mixtas (Damasio y López, 2020), lo cual se muestra notablemente evidente en el caso de la conjunción música-cine. Sin embargo, las nuevas capacidades que las aplicaciones tecnológicas están permitiendo en la observación paramétrica de las obras audiovisuales está provocando un fenómeno de distanciamiento en la perspectiva más extendida en los estudios sobre música de cine en la actualidad. El encaje y contraste entre las mediciones, en términos semióticos, de elementos del texto narrativo y de la partitura, se impone como la corriente metodológica más extendida en la actualidad, generando así un campo de datos resultantes de las investigaciones notablemente reducido, condicionado y limitado, para empezar, por el persistente paradigma de dualidades - pista de imagen/ pista de sonido, película/ partitura, compositor/ director, música preexistente/ original, diegética/ extradiegética, etc.- que reduce sustancialmente las posibilidades de aplicaciones creativas y didácticas de estos análisis.

Partiendo de este escenario, el proceso de investigación y documentación previa que sostiene el presente estudio viene a constatar una serie de problemas detectados en la bibliografía actual sobre música y cine que tienen, como pretendemos señalar en este estudio, una influencia directa y perniciosa sobre la formación y la labor profesional de los músicos y cineastas que trabajan sobre la música en el terreno cinematográfico

\section{De lenguajes y herramientas. Marco Teórico}

Es un debate recurrente el de la capacidad lingüística, expresiva y comunicativa de la música en general. En numerosas ocasiones, esta cuestión ha sido sintetizada en una pregunta: “¿Es la música un lenguaje universal...?”, y, previamente, y con mucho sentido: “Es la música un lenguaje?”. ${ }^{2}$ Sobre las cualidades y capacidades comunicativas intrínsecas de la música, sobre su relación con la sensibilidad y la inteligencia humanas, incluso con lo espiritual, se ha escrito hasta la saciedad. Ya René Descartes reconocía en la música el lenguaje del conocimiento indefinido de las pasiones (Gertrúdix, 2003, p. 29), y Arthur Schopenhauer consideraba la música como la más poderosa de las artes, ya que, en sus palabras, "no informa del mundo. Esto le permite expresar no emociones concretas, sino la naturaleza esencial de estas" (Arranz, 2010, p. 38). Un debate, el de la capacidad de expresión y comunicación de la música, en el que, con frecuencia, se confunde y se toma expresividad por semanticidad, error este que ha llevado a muchos autores, entre ellos Igor Stravinsky, a negar a la música la capacidad de lo expresivo (Colón, 1993, p. 20). José Luis Téllez nos aclara algunas diferencias y cuestiones sustanciales. Para empezar, el uso del término "lenguaje" para referirse a ciertas manifestaciones artísticas es, para este autor, tan frecuente como abusivo. El empleo del término solo puede entenderse como una pura metáfora. Su operatividad

2. Recientemente, desde la Escuela Superior de Música de Catalunya (ESMUC), la obra de Rubén López-Cano La música cuenta: (2020) actualiza y reorienta este debate, aunando perspectivas semiótica y cultural, aportando además una amplia reflexión sobre los tipos de exégesis musicales que recorren los estudios actuales, y sus puntos de encuentro con los análisis pictóricos y visuales clásicos y contemporáneos. 
real no solo es restringida sino, incluso, francamente engañosa. Esto es así "mientras no sea posible (y no lo parece) establecer un sistema de signos completo, capaz de describir e identificar los elementos que componen cualquiera de esos lenguajes hipotéticos y las leyes que rigen su utilización y aplicarlas de manera exhaustiva a un ejemplo concreto de modo similar al de un análisis gramatical" (Téllez, 2013, p. 63). Como señala López-Cano, la música, como el lenguaje verbal y otras manifestaciones culturales, no vive en la abstracción de reglas gramaticales ni significados asignados de antemano, sino que "los discursos irrumpen performativamente para hacer cosas a favor de quien los emite. Construyen y destruyen más allá de sus lógicas y reglas. Su pleno significado es alcanzado únicamente en el contexto, momento y circunstancias en que son emitidos" (López-Cano, 2020, p. 35). Umberto Eco cree encontrar, sin embargo, en la música, unas "estructuras sintéticas" que conforman un sustrato común para la comunicación, similar al descrito para el lenguaje por Noam Chomsky en su teoría de la Gramática Generativa Universal (De Arcos, 2006, p. 93). Leonard Bernstein llegará a situar este sustrato universal de una manera tan localizada y concreta como la de afirmar que se encuentra en la serie armónica. ${ }^{3}$ Ésta se caracteriza por establecerse a partir de atributos y relaciones físicas y matemáticas, y no estéticas o de otro tipo más relativo, motivo que podría ser probablemente el que llevará, a su vez, a Arnold Schönberg, a considerarla como sustrato común para todas las culturas. ${ }^{4}$

Aplicado a la teoría cinematográfica, Robert Stam considera, siguiendo a Batjin y Medvedev, que la pista de sonido correspondiente a la música debe considerarse portadora de "elementos lingüísticos" (Stam, 2001, p. 253). La indeterminación denotativa del lenguaje musical hace necesaria su interpretación cultural y lo convierte en un medio de expresión versátil capaz de interactuar con otros lenguajes. Así, la música, en su naturaleza sonora, forma parte del lenguaje audiovisual que utiliza el cine; sin embargo, su presencia se multiplica y se diversifica cuando entendemos la música como un lenguaje cuya presencia excede los límites sonoros (Viñuela, 2010, p. 108).

Más allá del debate lingüístico, si situamos el foco en términos de la experiencia receptiva de lo musical, encontramos que, desde esta aproximación, los detractores de las capacidades expresivas de la música sostienen, entre sus principales argumentos, el de situar esa capacidad expresiva y comunicativa en el propio sujeto receptor, y no en la propia música emitida. Cabría responder a este argumento postulando que, en ese caso, no solo la música es expresiva, sino que lo es en múltiples formas, y con un potencial de alcance infinito, ya que nos encontraríamos con tantos diferentes mensajes y cargas emocionales transmitidas como escuchantes receptores. Diferentes autores, provenientes principalmente del campo de la psicología de la percepción, así como de la sociología de los medios, han situado en el centro de la experiencia receptiva el fenómeno de la identificación emocional (Morin, 2001; Brown, 1994), destacando la idea, desde la perspectiva semiótica instaurada fuertemente por Christian Metz, de que, en la música, significante y significado coinciden y se auto homologan (Metz, 2001). En las coordenadas cinematográficas, esta experiencia, relativa a los personajes -ya sean reales o ficticios- presentes en el filme, se puede idear, planificar,

3. La serie armónica se define, en música, como la sucesión de los sonidos cuyas frecuencias son múltiplos enteros positivos de la de una nota base, llamada "fundamental" (Randel, 2009, p. 12).

4. Arnold Schönberg (1874-1951) desarrolló una gran obra didáctica y teórica, provocando esta última enormes polémicas al romper con los criterios estéticos de las escuelas anteriores e introducir lo aleatorio y lo matemático en los métodos de composición. 
diseñar, y poner en escena, construyendo un discurso que esté transmitiendo y manipulando tanto ideas como emociones.

Autores-cineastas como Jaime Camino van más lejos, y llegan a otorgar a la música capacidades como, por ejemplo, la de expresar el sentimiento del amor en el cine, directamente, además, a través de la instrumentación de los tres componentes musicales, a saber: melodía, ritmo y armonía: "La melodía expresa la idea y sentimiento del amor. El ritmo los sitúa en el tiempo. La armonía los hace comprensibles a los demás" (Camino, 1963, p. 53). En un proceso mucho más complejo y rico que los que pudieran determinar este tipo de transposiciones directas, la construcción de ese discurso narrativo, dramático y elocuente puede hacerse -se hace- sirviéndose de un director -de cine-, responsable de ese diseño y de esa arquitectura expresiva, intelectual y emotiva. Porque, con demasiada frecuencia, se habla de imágenes para englobar la expresión fílmica, cuando las imágenes son tan solo parte de la misma. ${ }^{5}$

En el centro del cuadro teórico clásico, y partiendo de la idea de semanticidad, encontramos la cuestión capital del funcionalismo. Autores contemporáneos plantean análisis complejos partiendo de la visión de la música fílmica desde el estricto uso funcional y desde la vigencia de un canon (García Martín, 2018, p. 389). Como nos recuerda Jaume Radigales, históricamente se dan dos corrientes principales en cuanto a la naturaleza, digamos "aplicada", de la música de cine: las corrientes funcionalistas y las corrientes esencialistas. Las primeras, las funcionalistas, entienden la música en el cine como una herramienta puntual, que cumple una serie de funciones concretas, prácticas, y añadidas al aparato fílmico. Esta es la corriente dominante en los estudios y entre los profesionales cinematográficos en todas sus especialidades y -sí, también hasta hoy- todas las épocas desde que fueron formuladas. Son muchos los autores que han abrazado esta corriente y han desarrollado taxonomías al respecto, entre las que destacan algunas, como la de los cuatro principios de Claudia Gorbman (invisibilidad, continuidad, inaudibilidad y unidad), ${ }^{6}$ e incluso las de reputados músicos de cine, quienes han dedicado esfuerzos a clasificar las funciones principales que, a su entender, competen a la música dentro del filme. Es el caso de Aaron Copland, para quien la música debe:

«- Crear una atmósfera más conveniente de tiempo y lugar.

- Subrayar refinamientos psicológicos: los pensamientos no expresados de un personaje o las repercusiones no vistas de una situación.

- Servir como una especie de fondo neutro.

5. En este punto consideramos conveniente aclarar que, en adelante, nos referiremos al concepto de "imagen fílmica" desde un punto de vista técnico, centrado en lo visual por oposición a lo auditivo. Cuando el concepto de "imagen" se presente con un sentido diferente - por ejemplo, filosófico, ligado al terreno de las ideas- será conveniente y puntualmente aclarado.

6. Claudia Gorbman, en Unheard Melodies establece unos criterios destilados de los usos musicales del cine clásico, a saber:

1. Invisibilidad del equipo de producción de la música

2. Inaudibilidad de la música

3. La música traduce emociones

4. Narrative cueing. Función semiótica, puntuación

a. Demostrativa: partes, estructura

b. Connotativa: Caracteriza el tiempo, lugar, la cultura...

Gorbman considera que la música puede crear completamente el sentido de una escena, o de una mirada (Chion, 1997, p. 122). 
- Dar un sentido de continuidad.

- Sostener la estructura teatral de una escena y redondearla con un sentido de finalidad» (De Arcos, 2006, p. 120).

Los planes de estudios de los programas sobre film scoring siguen basándose en este corpus hoy en día (Sánchez, 2002). No deja de ser llamativa la dificultad, o imposibilidad incluso, para encontrar en los escritos especializados, este tipo de clasificaciones aplicadas a las funciones que deben cumplir en un filme las aportaciones de los actores, los directores artísticos, los directores de fotografía, los guionistas, o los propios directores, sin ir más lejos. Sin embargo, los análisis y propuestas metodológicas que seguimos encontrando respecto a la música de las películas, siguen remitiéndose a la aplicación sistemática de estos listados de funcionalidades cerradas (Molina Sosa, 2020).

Las segundas corrientes teóricas, las que hemos denominado esencialistas, entienden la música como un todo en relación con la imagen y viceversa. Hablan de una consustancialidad del cine como arte "musical" en sí mismo. Afines a esta visión, el autor nos señala una serie de nombres de referencia significativos, como son Béla Balázs, Edgar Morin, Gilles Deleuze, o Charles Chaplin (Radigales, 2008, p. 32) Según Carlos Colón, las principales características comunes en los modelos esencialistas son:

- Consustancialidad (o inherencia básica).

- Relación de alquimia.

- Reciprocidad (influencia mutua y simbiosis).

- Demarcación (acotación del film como objeto) (Rodríguez Fraile, 2001, p. 43).

La línea esencialista, llevada a un extremo, podría desembocar en ideas como la desplegada por Ángel Fernández Santos para revertir el comentario de Robert Bresson sobre su propio filme Un condenado a muerte se ha escapado (Un condamné à mort s'est échappé ou Le vent souffle où il veut, 1956). Afirma Bresson sobre el filme: "Es una película bella, pero defectuosa, porque todavía tiene música", a lo que apostilla Fernández Santos: "Parece un juego a la paradoja, pero no lo es. Lo que en realidad dijo Bresson, como amable reproche a un trabajo suyo, es que su película aún tenía música, cuando toda verdadera película no debe tener música, sino ser música" (Fernández Santos, 2007, p. 137).

Como vemos, los estudiosos no muestran posturas unánimes al respecto y, si bien predominan las voces que separan claramente música y cine, encontramos incluso autores que, a lo largo de sus escritos sobre el tema, llegan a contradecirse a sí mismos, y estar unas veces de un lado y otras de otro. El francés Michel Chion, uno de los mayores y fundamentales autores sobre el sonido y la música de cine, nos ilustra sobre este tipo de enfrentamientos teóricos en su conocida obra La audiovisión, en un capítulo sobre la situación del sonido en general (más allá de la música) frente a la imagen fílmica:

"Esta función de agregado unificador, en la que el sonido desborda temporal y espacialmente los límites de los planos visuales, ha sido criticada por la doctrina que puede llamarse diferencialista, partidaria de que el sonido y la imagen actúen en zonas separadas. Es curioso que esta doctrina olvide criticar la misma decisión previa unificadora 
cuando se aplica a la imagen misma: aludimos al cuidado por la continuidad visual que preside la fotografía de casi todas las películas, sean mudas o sonoras (incluidas las de Godard, Duras, Syberberg) y que procura, en el nivel de las mediciones, los ajustes de luz y las dominantes del color, hacer de la película un conjunto. Viendo una película constituida por cuatrocientos o quinientos planos, ¿estaríamos dispuestos a percibir como una sucesión de quinientas unidades perfectamente distintas, como han intentado algunas películas experimentales?" (Chion, 1993, p. 44).

Nótese que, incluso al referirse a la corriente "no diferencialista" para la cuestión sonido/imagen, el razonamiento comienza hablando del agregado unificador que pretende defender. La noción de adición, de elemento extraño a agregar, persigue al sonido en general, y a la música en especial, desde todos los ángulos de los estudios.

Desde la perspectiva musicológica, que, como decimos, aporta, singularmente en el caso español, la mayor cantidad de trabajos en los últimos veinte años, las limitaciones vienen muy claramente definidas por cuatro enfoques predominantes: en primer lugar, la vocación histórica y archivística, centrada en la recuperación de obras, donde destaca la labor de autores como Josep Lluís Falcó o Matilde Olarte, o el grupo de investigación Música y cine en España: recuperación, inventario y difusión de un patrimonio cultural multidisciplinar, que estos mismos investigadores, junto a otros referentes en el terreno como Jaume Radigales, Joaquín López y Teresa Fraile Prieto vienen desarrollando en las últimas dos décadas (Falcó (2005), Fraile Prieto (2016), López González (2010), Radigales et al., 2009). La importante labor de este tipo de iniciativas supone un paso fundamental pero aún alejado del estudio de los procesos de creación, y de una perspectiva integradora de la teoría fílmica y la musical y la musicológica. Tanto Fraile Prieto (2016) como López González (2010) han reunido, a modo de estados de la cuestión, los corpus bibliográficos, así como las iniciativas académicas y divulgativas, en diversos ámbitos, relacionadas con el tema, especialmente en el territorio español, pero limitándose a la compilación y mínima descripción formal de los recursos, sin entrar en los preceptos teóricos que fundamentan los trabajos. En segundo lugar, los análisis musicológicos de obras musicales presentes en películas, siguiendo las metodologías historiográficas de autores como el mencionado Falcó, muy pegados en sus bases epistemológicas a la historia del arte, se suelen ceñir al análisis técnico de las partituras en liza, derivando en estudios cuyas conclusiones suelen intentar establecer estilos de composición, o técnicas instrumentales y orquestales más o menos habituales en determinados géneros, épocas o filmografías de tal o cual director, empresa productora o nacionalidad. Las saludables excepciones que analizan la implicación dramática, desde el punto de vista de la narrativa cinematográfica y la puesta en escena, como por ejemplo los trabajos de la musicóloga Laura Miranda (2018), se ciñen, desde esta perspectiva, en el análisis de las obras acabadas y contextualizadas en cuanto a su recepción espectatorial. En tercer lugar, y alejándose sustancialmente de la perspectiva fílmica, una amplia corriente de los estudios sobre música de cine provenientes del campo de la musicología, construyen su objeto de estudio sobre los repertorios de los compositores, estrictamente ceñidos a las partituras originales -lo que, por ejemplo, suele descartar casi toda la música diegética presente en las películas- presentes en los filmes, y se orientan a la puesta en valor de esas composiciones en términos estrictamente musicales, como parte, como decimos, de un repertorio extra cinematográfico. Obviamente, estos estudios poco pueden aportar al corpus teórico de la creación fílmica. En cuarto lugar, una corriente de estos estudios se dedica al estudio del cine musical, en cuanto 
género cinematográfico, limitando el análisis a este reducido grupo de películas de características tan específicas. Sobre este particular, sin embargo, contamos con referencias, tanto nacionales (Radigales, 2017) como internacionales (Altman, 1987) de cierto calado teórico, pero, como decimos, limitadas al cine de género musical.

\section{De la inefabilidad al desencuentro: Problemas Radicales}

Nos referimos, en primer lugar, y a la vista de lo constatado, a la existencia en los estudios fílmicos de un verdadero abismo entre lo referente al aparato visual, y lo referente al aparato sonoro, y, especialmente, en cuanto a la circunscripción de lo musical en el segundo. Las corrientes observadas, ampliamente divergentes en multitud de consideraciones, coinciden, sin embargo, prácticamente en su totalidad, en su vocación de separar la actividad fílmica de la musical, y en entender su relación en términos de adición, de acompañamiento, y de producción de dos realidades ontológica, funcional, y expresivamente, diferentes. En el campo teórico, el problema es evidente cuando autores de referencia, como José Luis Téllez, afirman que la música, codificada, actúa, sin embargo, al engrosar la obra fílmica, por sí sola. La condición previa de esta codificación parece condenarla, según este razonamiento, a su inmutabilidad. La relación se entiende, no solo como la de entidades separadas, sino jerarquizadas, en cuyo vínculo, la música es entendida y analizada, subordinada "a la narratividad fílmica" (Téllez, 2007, p. 45). Esta contundencia en la exclusión de lo musical de la propia narratividad fílmica es la base de buena parte de los problemas a los que nos enfrentamos. Los autores vigentes sobre la materia llegan a argumentar sobre testimonios que llegan, incluso, a situar las formas musicales del cine, no solo más allá del cine -donde el recurrente error es conformarse con la forma musical-, sino directamente en otras expresiones de naturaleza ni fílmica ni musical. Es el caso de la casi aporética reflexión de Leonard Rosenman, cuando encadena que la forma de la música de cine no es puramente musical, sino "una forma literaria, no musical" (De Arcos, 2006, p. 67). Incluso Russell Lack, autor imbuido de una visión es mucho más integradora, se ahoga rápidamente en el callejón de la semiótica, considerando la música como meramente denotativa antes de desencadenar "inacabables cadenas de connotaciones que desafían todo análisis semiótico" al sumarse a la expresión visual (Lack, 1999, p. 377). No ocurre lo mismo con el resto de las disciplinas artísticas involucradas en el cine, y de las que se nutre su praxis. Un proceso fotográfico por el que tratamos un negativo en blanco y negro, o con un fuerte virado a tonos azules, no es considerado como un añadido del campo de la fotografía al de la cinematografía, sino como una operación propiamente fílmica. Lo mismo sucede ante un diseño de vestuario victoriano, goyesco o fantástico, la ejecución de una coreografía de danza contemporánea, o un monólogo ejecutado por un actor extraído directamente de una obra teatral de Lope de Vega. De la misma manera que no se cuestiona que ese proceso fotográfico, ese diseño de vestuario, esa coreografía de danza, o ese texto teatral, son elementos cinematográficos, inherente y sustancialmente partes integrantes del aparato cine, la música de las películas, en cualquiera de sus infinitas formas, necesariamente también debe serlo. Cualquier problema técnico equivalente a los que sufren otras especialidades se achaca, en el campo de la música de cine, a la imposibilidad de combinar naturalezas ajenas. Esta circunstancia no puede ser achacable a la habitual rutina de posponer la inclusión de la música en las películas hasta la fase de postproducción, ya que, sin ir más lejos, los tratamientos fotográficos que utilizamos como ejemplo, 
también se dan en los procesos de postproducción. Y qué decir de los tratamientos digitales a los que las imágenes fílmicas se suelen someter en el cine de nuestros días. En cualquier caso, la asimilación de la música en el cine en general, como la suma de las músicas extra diegéticas añadidas en postproducción, es uno de los claros síntomas de los problemas que aquí estamos describiendo. Como consecuencia de esa praxis de la añadidura y el recortado y pegado, que tan pesadamente se ha impuesto a lo largo de los años, no están instauradas, ante las cuestiones musicales de la construcción del film, rutinas y protocolos propiamente fílmicos, que contemplen las soluciones a los problemas que puedan aparecer relacionados con la música. Esta constatación es gravísima para el terreno profesional. Un ejemplo ilustrativo es el consabido problema sobre la brevedad de las piezas musicales en el film. Es evidente que esta cuestión sólo puede suponer un problema si se piensa en términos estrictamente musicales, y no cinematográficamente. Se aborda como un problema de incompatibilidades la idea que el formato sonata, o poema sinfónico, o movimiento sinfónico, o incluso la canción, no se adaptan, debido a su duración en cuanto a pieza musical individual, a los diseños estructurales del montaje de imagen fílmico. Por supuesto que no, de la misma manera que el tiempo, materia prima fundacional del cine, no puede ser utilizado en sus formas establecidas en la vida real: días, horas, meses... Por ilustrar la cuestión técnicamente, podemos considerar que, siguiendo esa línea de ingenuidad en el pensamiento de la construcción fílmica, estaríamos ante el mismo problema que tiene un actor para decir y expresar con su cuerpo y su voz lo que considera suficiente para representar las ideas y sentimientos de su personaje, cuando por múltiples motivos técnicos y/o artísticos, el director recorta su intervención respecto a lo previsto en el guión. Un recorte que se puede dar en el rodaje y, sobre todo, en el montaje, donde el actor, elemento indiscutiblemente fílmico para toda la comunidad académica especializada y para toda la profesión práctica, tendrá, de hecho, muchísimo menos control sobre su trabajo, que el músico.

El segundo problema encontrado está fuertemente relacionado y derivado del anterior. Se trata de la asunción general de que el compositor de la música de cine es un creador procedente del mundo extra cinematográfico de la música, que se acerca al mundo del cine y en el que, a través de la interacción con el director de la película pertinente, añade su obra extra cinematográfica a la obra cinematográfica, momento este de la adición en el que esa obra estrictamente musical quizá se convierta en algo diferente e integrado en el aparato fílmico. ${ }^{7}$ La concepción profesional de los músicos de cine no ha variado sustancialmente desde la aparición del cine sonoro (Falco, 2005, p. 1058), y los mismos músicos de cine, en el devenir histórico profesional, no están exentos de esta carencia fundacional, de la incomprensión del carácter fílmico de la música de cine. Comentaba Manuel Vázquez Montalbán sobre la música de cine en la España de los años cincuenta: "Era una época en la que el cine todavía experimentaba lo del subrayado musical. Hay que admitir que a los subrayistas españoles se les iba la mano y consiguieron que hasta las comedias parecieran cine de terror, del pánico que comunicaban al espectador los hundimientos musicales que jalonan la acción" (Vazquez Montalban, 1971 p. 40). Sobre la década siguiente, afirmaba Jesús Franco, músico y director, en sus memorias: "Uno de los dramas de nuestro cine era que la música casi siempre estaba en manos de unos hombres quizá válidos para componer

7. Utilizaremos aquí la noción de aparato fílmico tanto desde un punto de vista estrictamente técnico, como desde el político y sociocultural, en la línea de Stuart Liebman en sus análisis sobre las teorías fílmicas de Jean Epstein (Liebman, 2009, pp. 16-35). 
zarzuelas, operetas de Celia Gámez o pasacalles de la tuna, pero que, aparte de haberse quedado en la escuela de mi maestro Conrado del Campo, no sabían nada de cine" (Franco, 2004, p. 204). Efectivamente, el feroz mundo de las orquestas, auditorios y compañías discográficas musicales ha fomentado y fomenta una actitud de distanciamiento de los músicos de cine hacia el carácter fílmico de sus composiciones $\mathrm{o}$, en algunos casos, directamente, hacia sus propias obras para cine, como son los casos del citado Igor Stravinsky o, aplicado al ámbito español, Luis de Pablo (Maire, 2018, p. 10). Diferentes autores reivindican sin cesar la valía musical pura de las obras y compositores fílmicos (Nieto, 2003, p. 10), y esta situación llega al paroxismo en actitudes como las tomadas por Philip Glass ante Martin Scorsese tras el montaje de las músicas de Kundun (M.Scorsese, 1997), sentenciando ante el director neoyorquino: "Tú tienes la película, yo tengo el disco" (Morgan, 2000, p. 241).

Por desgracia, la corriente más fresca y actual de estudios sobre la música y el cine, la que proviene en los últimos veinte años de las facultades de musicología, insiste en este enfoque a la hora de reivindicar la figura del compositor de música de cine. Se reivindica un determinado repertorio musical -el de la música de las películascomo parte sustancial del panorama de la música contemporánea (Fraile Prieto, 2016) (López González, 2010), y se aborda su estudio, técnicamente, desde la perspectiva estrictamente musical. La notable proliferación de textos académicos analíticos sobre música de cine registrada en los últimos años sitúa el componente musical externamente a los medios audiovisuales y analiza sus relaciones, en realidad, reduciendo éstas a la presencia de notas, acordes, compases, pero desde la partitura, y siempre sobre obras realizadas, cayendo en el paradigma del elemento añadido.

En la raíz de la problemática detectada, hemos percibido también la existencia de una cierta reticencia general entre la comunidad académica del cine hacía tener que lidiar con cuestiones musicales. A la hora de describir la música, tradicionalmente la elección ha estado entre la mistificación a través de un uso excesivo de adjetivos ${ }^{8}$ y el lenguaje técnico de la musicología (Lack, 1999, p. 235). Desde esta aproximación, más contemporánea y de cierta relevancia en la comunidad universitaria española, encontramos múltiples aproximaciones a nuestro objeto de estudio. Por desgracia, esta multiplicidad de propuestas musicológicas no logra evitar cierto parecido entre ellas y, lo que es más preocupante, un notable desconocimiento general, tanto de la teoría fílmica -limitada, además, cuando aparece, al discurso tutor-, como, notablemente, de la realidad profesional del mundo cinematográfico. El lenguaje musical y los estudios musicológicos se han ido configurando, de manera extensiva en nuestro campo de estudio, como una suerte de agentes extraños a los que nadie, ni profesionales ni académicos, se atreve a acercarse ni a interactuar. En el caso de los académicos del cine, en su inmensa mayoría neófitos en el estudio de lo musical, no han sabido, o no se han atrevido, a nombrar y utilizar profesionalmente lo musical desde el lugar natural desde el que podrían y deberían hacerlo, es decir, desde lo fílmico. Este rechazo a asumir una perspectiva necesaria, pero que se sustenta en unos códigos desconocidos, les ha empujado a la cómoda solución de separar lo musical de lo fílmico y a limitarse a comentar su "añadido". Pero lo cierto -siguiendo a Nicholas Cook- es que todos los que trabajamos sobre el tema lo hacemos. De lo

8. Sobre las tremendas dificultades de los directores de cine para transmitir sus ideas a los músicos de cine, es ilustrativa la lectura de la compilación de entrevistas con músicos de cine compilada por David Morgan (2000). 
inefable no paramos de hablar, y utilizamos palabras para decir lo que la música no puede decir, para decir lo que queremos expresar por medio de la música, lo que la música significa para nosotros. Y a la postre son, en buena medida, las palabras las que determinan lo que la música significa para nosotros (Cook, 2006, p. 164). Como señala Vladimir Jankélévitch,

"Desgraciadamente, la música en sí misma es un no-sé-qué tan incomprensible como el misterio de la creación -aquel misterio del que sólo se capta el antes o el después: el antes, esto es, la psicología, la caracterología y la antropología del creador; el después, es decir, la descripción de lo creado-. ¿Cómo captar el divino instante entre ambos, el que más nos importaría conocer, y, en cambio, el que más obstinadamente se nos escapa? Asimismo, el irritante y decepcionante secreto de la música se oculta y parece reírse de nosotros" (Jankélévitch, 2005, p. 161).

Éste es el tipo de estupor que se rastrea con facilidad por todos los rincones de nuestro campo de estudio, insistimos, tanto en la teoría como en la praxis fílmica. Existen infinidad de ejemplos, reducidos habitualmente en los textos a lo anecdótico sobre cómo los directores y productores demandan a los músicos llenar de notas el metraje sin lograr transmitir el sentido de sus peticiones. David Shire lo compara con la violenta situación en la que, a un cómico, en cualquier situación fuera de contexto o planificación, se le exige que diga algo gracioso. “¿Sobre qué?” reclama el compositor (Morgan, 2000, p. 90). Claramente asistimos, constantemente, a la necesidad de una conversación pendiente sobre cine. ${ }^{9}$

Estos problemas comunicacionales se agravan con las limitaciones de tiempo y presupuesto que suelen aplicarse a la producción de la música en las películas. La tensión y el riesgo de ineficiencia es aún mayor si tenemos en cuenta que los músicos sólo trabajan, en cierto sentido, con una oportunidad. Es decir, un solo presupuesto destinado a una sola sesión o sesiones de grabación (Morgan, 2000, p. 242), y siempre trabajando contrarreloj y sobre un montaje visual cerrado. Las excepciones a este modelo de producción provocan desconcierto incluso entre los cineastas más libres y experimentales. Valga como ejemplo la visión de Ennio Morricone sobre la conversación sostenida por Stanley Kubrick y Sergio Leone al hilo de la musicalización de ciertas escenas de Hasta que llegó su hora (Once upon a time in the west, 1968), dirigida por Leone y musicalizada por Morricone. Kubrick se muestra conmovido y admirado por la naturalidad y efectividad con que la música encaja, tanto dramática como sincrónicamente, con las imágenes. Leone responde: "La música la grabamos antes. La escena, los movimientos y los intervalos de la cámara los hice a partir de la música que ya teníamos y que se había tocado a todo volumen en el plató". "Claro, por supuesto" dijo Kubrick. El comentario que añade el compositor romano es ilustrativo: "Claro, pero no evidente. Porque en el cine, lo último que se piensa suele ser en la música. (Morricone, 2016, p. 135). Y es que, históricamente, el mundo del cine, en general, no ha mirado con buenos ojos a sus músicos, hasta llegar al punto de desconfiar de su actitud hacia el trabajo. El productor de Hollywood Irwin Balezon enumeraba, en 1975, toda una lista de argumentos por los que desconfiar de los músicos autónomos como compositores para cine. Según Balezon, los productores:

9. Para un amplio desarrollo de esta cuestión, ver a Lazaro (2017). 
"Dudan de su lealtad -la de los músicos- a la industria y no creen que comprenda los propósitos y aspiraciones del negocio fílmico.

- Se muestran inseguros sobre su habilidad a la hora de comunicarse con el músico a un nivel de lenguaje común (el viejo síndrome intelectual/ ignorante).

- Temen que el compositor de concierto no encaje en el equipo de producción; que su ego o difícil personalidad trastorne la fluida operación de poner música al film; que vaya a atraer la atención de todo el mundo.

- Desconfían de su facultad y deseo de acatar instrucciones explícitas, de que tenga el trabajo hecho rápida y eficientemente y de que sea capaz de escribir una buena música comercial (reconocen también que su récord de ventas en la taquilla como escritor de canciones es cero).

- Recelan de que su inexperiencia en el medio cinematográfico cueste retrasos y dinero; de que el resultado sea una sesión de grabación inútil; de que el no saber cómo utilizar el equipo básico mecánico y técnico cause una grave interrupción en el proceso de musicalización de la película.

- Les horroriza que vaya a escribir música ultra disonante que sea inapropiada para el film, que eleve el presupuesto (van a tener que contratar a otro compositor para que les termine el encargo) y que provoque hostilidad en la audiencia” (De Arcos, 2006, p. 44).

Esta situación, recogida por María de Arcos sobre un contexto de hace más de cuarenta años, podría ser tomado por anticuado, pero la industria más actual y dominante nos muestra los mismos complejos y problemas. En el verano de 2019, el compositor Fernando Velázquez, responsable de la música de éxitos comerciales como Un monstruo viene a verme (J. A. Bayona, 2016) u Ocho apellidos vascos (E. Martínez Lázaro, 2014), reconocía, ante un auditorio de músicos y musicólogos, por un lado, que las partituras de ese tipo de películas no presentaban gran riesgo o experimentación, y se ajustaban a la lógica de una industria fílmica determinada pero que, por otro lado, podían provocar para el compositor el conflicto de tener que justificarse constantemente ante el mundo de la música por presentar partituras consonantes y en do mayor. ${ }^{10}$

Desde la perspectiva metodológica, otro problema que nuestro campo de estudios encuentra frontalmente es que la música aplicada al cine no se puede, por definición, estudiar independientemente del soporte audiovisual, y sin embargo así lo hacemos en numerosas ocasiones. Los calificativos valorativos sobre músicas compuestas para cine son promulgados en cascada desde multitud de voces, sin hacer una sola mención a su funcionamiento audiovisual, narrativo, expresivo, o estructural en el filme. La música, si es bella, estética e individualmente reconocible, colecciona halagos, premios e ingresos de ventas y difusión en soportes no fílmicos. La partitura de Ennio Morricone para el filme La misión (The mission, Roland Joffé, 1986), es elogiada en los siguientes términos en palabras de Heriberto y Sergio Navarro, en su obra sobre música de cine de 2003:

"La música de Ennio Morricone para La misión cautivó al mundo por la belleza de sus melodías, adquiriendo un protagonismo especial y haciendo que muchos espectadores

10. Declaraciones de Fernando Velázquez en el XVII Curso de análisis musical UIMP. Cuenca, 2019. 
permanecieran en la sala de proyección durante los créditos finales por el mero hecho de disfrutar de la composición. Se trata de una partitura que ha servido para dar a conocer a mucha gente la música de cine, con una edición discográfica que no solo se ha convertido en cita obligada para todos los aficionados, sino que ha sido adquirida aisladamente por millares de personas no por su valor como banda sonora, sino por el atractivo y la belleza de la música en sí" (Navarro y Navarro, 2003, p. 330).

La relevancia de la partitura en cuestión es valorada sin ningún tipo de criterio cinematográfico, y, lo que es más inquietante desde el punto de vista de la música de cine, considera que este valor estrictamente musical "ha servido para dar a conocer a mucha gente la música de cine", tratando este fenómeno, el de la "música de cine", exactamente como si de un género musical se tratara -como el blues, el flamenco, o la cumbia villera, por ejemplo- y, a su vez, asumiendo una uniformidad o estrato común de cara a su valoración de la etiqueta "música de cine", en el que ningún elemento cinematográfico es tenido en cuenta para apreciar el trabajo de la composición musical.

Dado este estado de la cuestión, es nuestro propósito, intentando aprovechar el reverso de esta situación, posicionarnos en contra de este problema de inefabilidad, tanto en la praxis, como en el análisis y el estudio de lo fílmico en cuanto musical, precisamente desde la base de defender la naturaleza fílmica de la música de cine, entendiendo, con Sergei M. Eisenstein, la música, no al servicio de la imagen, sino como la voz interior de esas imágenes (Lack, 1999, p. 61). Una sola cosa.

\section{Elementos para una discusión prospectiva}

¿Sobre qué base asentar, por tanto, la discusión que nos permita apuntar vías, orientaciones o propuestas dirigidas hacia las soluciones de los problemas planteados? Quizá para encarar este planteamiento en clave problemática, es adecuado volver a la raíz de los síntomas y partir de lo que Theodor Adorno y Hans Eisler, pioneros en este tipo de teorización sobre nuestro tema, denominaron la "paradoja de la música" en el cine (Adorno y Eisler, 1981, p. 106). Esta se reduce a la consideración de que aquélla debe renunciar a ser ella misma, y que el músico no puede expresarse a sí mismo. La primera de las dos consideraciones de Adorno y Eisler al hilo de su "paradoja", la referida a la pérdida de naturaleza de la música en la operación, se ajusta a nuestra visión teórica. De hecho, es precisamente esa transformación ontológica de la expresión musical en expresión fílmica, la que necesita suceder para eliminar, tanto la noción del añadido, como las presuntas incompatibilidades entre distintos medios de expresión. La música debe transformarse en cine. En cuanto a la segunda apreciación en la paradoja de Adorno y Eisler, la referida a la imposibilidad del músico de expresarse a sí mismo, ésta tiene una evidente doble lectura al hilo de la consideración anterior. Por un lado, siguiendo la misma lógica, el músico no podrá, efectivamente, expresarse a sí mismo en cuanto músico, pero en cambio, si esa transformación de la música en cine se produce, se estará expresando en términos de cine, es decir, como cineasta. Este paradigma es exactamente igual de válido para el guionista, el fotógrafo, el diseñador de vestuario o, por supuesto, el actor. Y para expresarse en términos de cine esto no es necesario sentarse en la silla del director. Como el resto de los creadores colectivos del film, el músico puede, y debe, hacer cine, dirigiendo, desde su parcela 
de trabajo, la película. Esta constatación es fácil de entender si hacemos el ejercicio de valorar la interpretación de los actores dependiendo de las claves musicales que la partitura otorga a la escena. Planteamos una forma de autoría -de dirección- muy poco estudiada, pero autores como José Luis Téllez, Conrado Xalabarder o Michel Chion han aportado algunas ideas alrededor de este enfoque. Sobre la idea específica de la autoría fílmica a través del uso de la música, Michel Chion aporta un ejemplo interesante sobre el filme Casablanca (M. Curtiz, 1941), con partitura de Max Steiner. Destaca el autor que, aun no siendo casi ningún tema musical obra del propio Steiner, la música está dirigida minuciosamente para, escena por escena, narrar la historia muy por encima de un producto de factoría (Chion, 1997, pp. 131-132). El objetivo es, en palabras de S. M. Eisenstein, "saber orquestar y equilibrar el todo, de modo que ninguno de los aspectos particulares escape a las leyes del conjunto, a la unidad de composición" (Vericat, 2003, p. 31). Esa "orquestación" es buena parte de la labor del director de cine. Hacer funcionar todos los elementos en un sentido, y en términos puramente fílmicos. Y colaborar con esa labor es la llamada a la que el músico de cine, como el resto de los profesionales especializados que intervienen en la construcción fílmica, debe responder. Una colaboración que Adorno y Eisler sí llegan, en cambio, a identificar -como ya sugería más arriba Ennio Morricone- como necesaria en términos de planificación, en el momento que localizan como causa fundamental de los problemas de la música de cine, la no planificación conjunta y retroalimentada de la música con el resto de los elementos de la película en construcción (Adorno y Eisler, 1981, p. 128).

\section{Conclusiones}

Establecemos, por tanto, y a modo de conclusión final, dentro de esta crítica sobre la situación y tratamiento, tanto teórico como práctico, de la utilización de la música en el cine, la constatación de una serie de graves problemas de diversos índoles, pero que vienen a confluir en su origen en la separación de la expresión musical aplicada al cine de la propia expresión fílmica, y en el carácter estrictamente musical de los profesionales encargados de originar las piezas musicales destinadas a la creación fílmica, con la consiguiente segregación de la labor del compositor de cine frente al resto de los creadores fílmicos. Las rutinas profesionales y los estándares de producción responden a esta confusión y mala praxis original, pero también el grueso de la teoría académica al respecto, tanto desde el ámbito fílmico como del musicológico, que ha asumido los clisés y los conceptos derivados del error original de separar, posponer y añadir la sustancia expresiva musical, a otra sustancia expresiva ontológicamente diferente, la fílmica. Las directrices para corregir esta marcada tendencia habrán de llegar desde la articulación de un nuevo marco teórico sobre el que desarrollar una concepción fundamentalmente fílmica de la música de cine, y de una nueva formación de los profesionales destinados a ejecutar esta labor en el entorno industrial, así como una nueva disposición de las rutinas, roles y métodos de trabajo dentro de las producciones cinematográficas.

Simplificando al máximo, y con el objetivo de aclarar el enfoque que planteamos, proponemos, por tanto, en primer lugar, establecer la figura del director de cine como responsable fundamental de los recursos y modos de expresión de la música en la obra cinematográfica; y, en segundo lugar, y en contra de lo que buena parte 
de la historia del cine y la inmensa mayoría de la bibliografía teórica consultada nos dicen, considerar que el director de cine debe ser músico -en la misma medida que es fotógrafo, intérprete, diseñador de vestuario o decorador- pero que, sobre todo, el músico de cine debe ser cineasta, ya que lo que hace es cine. Esta concepción que proponemos contempla, sin embargo, en el panorama profesional actual, un estado de las cosas bien diferente, y dentro de él, una serie de prácticas muy extendidas que no pueden ser asumibles en pos de la coherencia con la naturaleza fílmica de la música de cine. ${ }^{11}$

\section{Bibliografía}

Adorno, T. W. y Eisler, H. (1981). El cine y la música. Madrid: Fundamentos.

Altman, R. (1987) The American Film Musical. Indiana: Indiana University Press. Bloomington.

Arranz, V. (2010). Nueva concepción del sonido audiovisual y los efectos expresivos en el cine contemporáneo. [Tesis doctoral inédita]. Universidad Rey Juan Carlos de Madrid: Madrid.

Brown, R. (1994). Overtones and Undertones: Reading film music. Berkeley (CA): University of California Press.

Camino, J. (1963). Música de cine. Nuestro Cine, 17, pp. 52-53.

Chion, M. (1993). La audiovisión. Barcelona: Paidós.

Chion, M. (1997). La música en el cine. Barcelona: Paidós.

Colón, C. (1993) Introducción a la bistoria de la música en el cine. La imagen visitada por la música. Sevilla: Facultad de Ciencias de la Información de la Universidad de Sevilla.

Cook, N. (2006) De Madonna al canto gregoriano. Una muy breve introducción a la música. Madrid: Alianza.

Damasio, M. J. y López Díez, J. (2020). Reflexión sobre un punto de inflexión en las metodologías de investigación en comunicación audiovisual. Comunicación y métodos, 2(1), pp. 4-6. https://doi.org/10.35951/v2i1.73

De Arcos, M. (2006). Experimentalismo en la música cinematográfica. Madrid: Fondo de Cultura Económica.

Falco, J. (2005). El compositor de cine en España: la generación del 89. Revista De Musicología, 28(2), pp. 1051-1077. https://doi.org/10.2307/20798118

Galindo Pérez, J. M. (2018). Los entresijos de la mirada: una propuesta metodológica para analizar la praxis fílmica. Área Abierta, 18(3), pp. 461-476. https://doi.org/10.5209/ARAB.59423

Garcia Martin, J. (2018). La musicalización diegética de la crisis en el cine negro holliwodiense de los años 40. La música clásica como signo del conflicto. Área Abierta, 18(3), pp. 389-407. https://doi.org/10.5209/ARAB.58492

Gertrudix, M. (2003). Música y narración en los medios audiovisuales. Madrid: Ediciones del laberinto.

Gonzalez Requena, J. (2006). S.M. Eisenstein: lo que solicita ser escrito. Madrid: Cátedra.

Fernandez-Santos, A. (2007). La mirada encendida. Escritos sobre cine. Barcelona: Debate.

Fraile Prieto, Teresa. Música de cine en España. Crecimiento y consolidación de una disciplina. La Albolafia: Revista de Humanidades y Cultura, n. 9, 2016, pp. 11-30. Recuperado de http://albolafia.com/trab/LaAlbolafia_N9\%28octubre2016\%29.pdf

Franco, J. (2004.) Memorias del tío Jess. Madrid: Aguilar.

Jankelevitch, V. (2005). La música y lo inefable. Barcelona: Alpha Decay.

Lack, R. (1999). La música en el cine. Madrid: Cátedra.

11. El protocolo más evidente y habitual en estas coordenadas sería el de la utilización de músicas preexistentes, producidas en y para un ámbito puramente musical, que pasan a integrarse en un material fílmico con posterioridad. En este caso, obviamente, no pretendemos aspirar a que los músicos autores de estas obras sean considerados o tratados como cineastas. 
Lazaro, J. A. (2017). El estupor del cineasta ante lo musical. En: Arce, J. y Fraile, T. (eds.), Música y medios audiovisuales: Análisis, investigación y nuevas propuestas didácticas (vol. I). Alicante: Letra de Palo, pp. 227-242.

Liebman, S. (2009). Espacio, velocidad, revelación y tiempo: las primeras teorías de Jean Epstein. Archivos De La Filmoteca, 0(63), pp. 16-35. Recuperado de https://www.archivosdelafilmoteca.com/index.php/archivos/article/view/65

López-Cano, R. (2020). La música cuenta. Retórica, narratividad, dramaturgia, cuerpos y afectos. Barcelona:ESMUC.Recuperadodehttp://www.esmuc.cat/spa/La-Escuela/Servicios/Biblioteca/ Publicaciones/Libros/La-musica-cuenta.-Retorica-narratividad-dramaturgia-cuerpo-y-afectos

López González, J. (2010). Los estudios sobre música y audiovisual en España: hacia un estado de la cuestión. Trípodos. Facultat de Comunicació i Relacions Internacionals Blanquerna. 26, pp. 53-66. Recuperado de https://www.raco.cat/index.php/Tripodos/article/view/187675.

Maire, J. L. (ed.). (2018). Luis de Pablo al habla. Madrid: Fundación Juan March.

Metz, C. (2001). El significante imaginario. Barcelona: Paidós.

Miranda, L. (2018). Canciones en el cine español. Periodo de autarquía (1939-1950). Santander: Shangrila.

Molina Sosa, J. (2020). Metodologías aplicadas a la crítica de Música de Cine: El uso del leitmotiv y su funcionalidad y articulación en "El Imperio Contraataca". Comunicación $Y$ Métodos, 2(1), pp. 76-89. https://doi.org/10.35951/v2i1.62.

Morgan, D. (2000). Knowing the score. New York (NY): Harper Entertainment.

Morin, E. (2001). El cine o el hombre imaginario. Barcelona: Paidós.

Morricone, E. (2016). En busca de aquel sonido. Barcelona: Malpaso.

Navarro, H. y Navarro, S. (2003). Música de cine: historia y coleccionismo de bandas sonoras. Madrid: Ediciones Internacionales Universitarias.

Nieto, J. (2003). Música para la imagen. La influencia secreta. Madrid: Iberautor/ SGAE.

Radigales, J. (2008). La música en el cine. Barcelona: UOC.

Radigales, J. (2017). Introducción a las bases metodológicas para el estudio del cine documental en España. En: Arce, J. y Fraile, T. (eds.), Música y medios audiovisuales: Análisis, investigación y nuevas propuestas didácticas (vol. I). Alicante: Letra de Palo, pp 17-20.

Radigales, J., Falcó, J., Olarte, M., López, J., \& Fraile Prieto, T. (2009). Música y cine en España: inventario documental-analítico (1989-2005). Revista De Musicología, 32(2), 665-673. https:// doi.org/10.2307/41959291

Randel, D. (ed.). (2009). Diccionario Harvard de música. Madrid: Alianza.

Rodriguez Fraile, J. (2001). Ennio Morricone. Música, cine e historia. Badajoz: Diputación de Badajoz.

Saitta, C. (2012). La banda sonora, su unidad de sentido. Cuaderno 41. Centro de Estudios en Diseño y Comunicación, pp 183-201. https://doi.org/41

Sánchez, O. J. (2002). Música e Imagen. San Luis: Universidad Nacional de San Luis. Recuperado en http://prodmusical.unsl.edu.ar/apuntes/La\%20musica\%20en\%20el\%20cine.pdf

Stam, R.. Teorías del cine, Barcelona: Paidós, 2001.

Tellez, J. L. (2007). Ver, oír. En J. Talens y S. Zunzunegui (eds.), Contracampo. Ensayos sobre teoría e bistoria del cine, pp. 37-54. Madrid: Cátedra.

Tellez, J. L. (2013). Paisajes imaginarios. Escritos sobre música y cine. Madrid: Cátedra.

Vazquez Montalban, M. (1971). Crónica sentimental de España. Barcelona: Lumen.

Vericat, D. (2003). Silencio, se habla. El cine según sus directores. Madrid: T \& B Ediciones.

Viñuela, E. (2010). La música popular de la literatura al cine: lenguaje, discurso y significados. Alta Fidelidad y The Commitments. Arbor, 186(741), pp. 107-116. http://dx.doi.org/10.3989/ arbor.2010.741n1011 